\title{
Stanovisko výboru České společnosti pro aterosklerózu k doporučením ESC/EAS pro diagnostiku a léčbu dyslipidemií z roku 2019
} \author{
Pavel Kraml ${ }^{8}$, Hana Rosolová9 ${ }^{9}$ Vladimír Soška ${ }^{10}$, Tomáš Štulc ${ }^{1}$, Zuzana Urbanová ${ }^{11}$ \\ 'III. interní klinika 1. LF UK a VFN v Praze \\ 2Interní klinika 2. LF UK a FN Motol, Praha \\ ${ }^{3}$ Centrum experimentální medicíny IKEM, Praha \\ 4III. interní gerontometabolická klinika LF UK a FN Hradec Králové \\ ${ }^{5}$ Centrum kardiovaskulární prevence 1. LF UK a Thomayerova nemocnice, Praha \\ ${ }^{6}$ Centrum kardiovaskulárni a transplantační chirurgie, Brno \\ 'III. interní klinika - nefrologická, revmatologická a endokrinologická LF UP a FN Olomouc \\ 8II. Interní klinika 3. LF UK a FN Královské Vinohrady, Praha \\ ${ }^{9}$ II. interní klinika LF UK a FN Plzeň \\ ${ }^{10}$ Oddělení klinické biochemie FN u sv. Anny v Brně \\ "Klinika dětského a dorostového lékařství 1. LF UK a VFN v Praze
}

Michal Vrablík', Jan Pitha ${ }^{2,3}$, Vladimír Blaha ${ }^{4}$, Renata Cífková5, Tomáš Freiberger ${ }^{6}$, David Karásek7,

\section{Úvod}

V srpnu 2019 byla publikována nová verze doporučených postupů $\mathrm{k}$ diagnostice a léčbě dyslipidemií autorů zastupujících Evropskou kardiologickou společnost (ESC) a Evropskou společnost pro aterosklerózu (EAS) [1]. Opět se jedná o komplexní a rozsáhlý materiál, který lze považovat za referenční - reviduje důkazy, o které opíráme diagnostické a léčebné postupy, ale s ohledem na rozsah a komplexnost materiálu jej pravděpodobně nebudeme používat $v$ denní praxi.

Výbor České společnosti pro aterosklerózu (ČSAT) zpracoval následující stanovisko jako souhrn nejdůležitějších a významných změn, které uvedený dokument odlišují od předcházejících guidelines ESC/EAS z roku 2016 a od Stanoviska ČSAT k těmto doporučeným postupům publikovaného v roce 2017 [2,3]. Výbor ČSAT považuje doporučení ESC/EAS 2019 pro management dyslipidemií za vhodná i pro zdravotní péči v České republice.

Stanovisko nenahrazuje komentovaná doporučení a zájemcům o detailní znění doporučujeme k prostudování původní kompletní text. Při srovnání současného a předchozího Stanoviska ČSAT z roku 2017 zůstávají v platnosti obecná pravidla hodnocení důkazů pro doporučení jednotlivých intervencí i použité formulace, které z nich vyplývají (je doporučeno, má být zváženo, může být za určitých okolností zváženo, není doporučeno); současné Stanovisko však komentuje důležité změny, zahrnující i tabulkové shrnutí novinek.

\section{Stanovení kardiovaskulárního rizilka}

Pro stanovení kardiovaskulárního (KV) rizika se v nových guidelines objevují tabulky SCORE extendované do věku
70 let a omezené výší hodnot celkového cholesterolu použitého při výpočtu na $7 \mathrm{mmol} / \mathrm{l}$. Osoby s hladinou celkového cholesterolu $\geq 8 \mathrm{mmol} / \mathrm{l}(\mathrm{LDL}-\mathrm{C} \geq 4,9 \mathrm{mmol} / \mathrm{l})$ musí být považovány za možné nositele familiární hypercholesterolemie, kteří jsou automaticky klasifikováni jako vysoce rizikoví. Pro Českou republiku jsou doporučeny tabulky pro vysoce rizikové populace (tab. 1). V brzké době se dočkáme národně specifických tabulek pro Česko. Výhodné je použití elektronické verze SCORE, která je snadno dostupná z www.heartscore.org.

Nová doporučení se vracejí k hodnocení stavů spojených $\mathrm{s}$ velmi vysokým cévním rizikem na základě zobrazovacích metod. Zdůrazňují roli vyšetření kalciového skóre koronárních tepen (CAC), které má být zváženo (při dobré dostupnosti) ke zpřesnění rizika u osob ve střední rizikové kategorii. Podobně Ize použít vyšetření karotických nebo femorálních tepen pomocí duplexního ultrasonografického vyšetření. Jednoznačný nález aterosklerotického plátu je důvodem k reklasifikaci nemocného do úrovně velmi vysokého rizika. Schéma 1 uvádí rozdělení kategorií kardiovaskulárního (KV) rizika s výčtem jednotlivých klinických situací rozhodných pro kategorizaci pacienta. Nově se $v$ textu guidelines objevuje kategorie nemocných $\mathrm{s}$ rekurentní aterotrombotickou príhodou do 2 let po první události při zavedené léčbě. Tito nemocní mají být považováni za extrémně rizikové a vyžadují maximální intenzitu intervence.

Dủležité je připomenout, že riziko zvyšují další modifikující faktory (sociální deprivace, psychiatrické komorbidity, hypertrofie levé komory srdeční, nealkoholová jaterní steatóza, fibrilace síní a další, viz rámeček 4 originálního dokumentu) [1]. Tyto modifikátory rizika 
nabývají na důležitosti zejména u osob ve střední rizikové kategorii, u kterých mohou usnadnit rozhodování o volbě hypolipidemické strategie.

K otázce vlivu HDL-cholesterolu (HDL-C) na modifikaci celkového rizika ASKVO (aterosklerotického kardiovaskulárního onemocnění) přispěly nové epidemiologické i genetické studie. Nadále platí, že nízká hladina HDL-C významně zvyšuje KV-riziko. Doporučení ESC/EAS 2019 poprvé uvádějí, že koncentrace HDL-C > 2,1 mmol/I u mužů a > 2,3 mmol/l u žen nejsou spojeny s redukcí rizika a mohou jej dokonce zvyšovat.

Ostatní zásady posuzování KV-rizika se nemění ani nejsou považovány za kontroverzní. U mladších osob se doporučuje tabulka relativního rizika nebo stanovení tzv. vaskulárního věku (srovnání věku vyšetřovaného s věkem osoby se stejným vypočteným rizikem dle SCORE při optimální konstelaci rizikových faktorů). V českých podmínkách využiváme národně specifické tabulky konstruované na základě epidemiologických dat z národních sledování.

\section{Laboratorní vyšetření lipidů a lipoproteinů} Doporučení nově vyzdvihují roli apolipoproteinu B (apoB) při hodnocení rizika ASKVO. Stanovení koncentrace $a p o B$ je doporučeno preferovat zejména u osob s velmi nízkou hladinou LDL-cholesterolu (LDL-C), hypertriglyceridemií, diabetem či metabolickým syndromem. Koncentrace apoB může být použita pro diagnostiku a screening i v rámci managementu pacientů s dyslipoproteinemií (DLP) jako alternativa LDL-C. V uvedených situacích riziko ASKVO reflektuje i non-HDL cholesterol, jehož vyšetření není spojeno s dodatečnými náklady.

Poprvé se v doporučených postupech objevuje „povinné" vyšetření koncentrace lipoproteinu(a) u všech osob alespoň jedenkrát $v$ životě. Pacienti s koncentracemi Lp(a) > 180 mg/dl (430 nmol/l) mají celoživotní riziko shodné s nemocnými s familiární hypercholesterolemií. Zjištění vysoké koncentrace Lp(a) může sloužit ke změně kategorie rizika.

Další obecná doporučení o vyšetřování krevních lipidů a lipoproteinů zůstávají nezměněna. Pro určení míry KV-rizika pomocí SCORE zůstává hlavním parametrem hladina celkového cholesterolu. LDL-C je nadále hlavním léčebným cílem, determinantem rizikovosti i screeningovým parametrem; může být nahrazen koncentrací apoB. Zejména nízká hladina HDL-C modifikuje dále riziko a má být vyšetřena $v$ rámci screeningu i před zahájením léčby. Navíc zjištění HDL-C potřebujeme pro určení hladiny non-HDL-cholesterolu, indikovaného ve stejných situacích jako hodnocení apoB.

\section{Změny v doporučení pro vyšetření sérových \\ lipidů a lipoproteinů \\ - koncentrace apoB může být použita jako primární parametr pro screening, diagnostiku a management nemocných s DLP místo LDL-C \\ - hladina Lp(a) má být vyšetřena minimálně jedenkrát v životě $\mathrm{k}$ identifikaci osob s velmi vysokými hladi- nami (> $180 \mathrm{mg} / \mathrm{dl}$ nebo $430 \mathrm{nmol} / \mathrm{l}$ ), jejichž riziko je ekvivalentní riziku pacientů s familiární hypercholes- terolemií \\ - stanovení koncentrací lipidů a lipoproteinů ve vzor- cích krve odebraných bez předchozího lačnění ne- považujeme nadále v našich podmínkách za vhodné, ale může být použito $v$ rámci screeningových aktivit s dostatečnou přesností}

\section{Cílové hodnoty lipidů a lipoproteinů}

Základním léčebným cílem zưstává i v poslední verzi doporučených postupů LDL-cholesterol (LDL-C), sekundárními léčebnými cíli jsou koncentrace apoB

Schéma 1. Kategorie KV-rizika. Upraveno podle [1]

velmi vysoké riziko
- klinicky anebo zobrazovací metodou prokázané
KVO aterosklerotické etiologie (ASKVO);
ASKVO zahrnuje předchozi AKS (IM nebo
nestab. AP), stabilní AP, koronární revaskularizace
(PCI, CABG a jiné arteriální revaskularizace),
CMP a TIA a ICHDK; za ASKVO jednoznačně
prokázané zobrazovací metodou považujeme
nález nemoci více koronárních tepen se stenózou
2 velkých epikardiálních tepen > 50\%), nebo
významné AS změny karotid detekované
ultrasonograficky
- DM s orgánovým postižením anebo prítomnost
nejméně 3 velkých RF; časně vzniklý DM1T
s dobou trvání > 20 let
- CKD 4. a 5 . stupně (eGFR < 0,5 ml/s/1,73 m²)
- vypočtené riziko fatální KV-přihody pomocí
SCORE $\geq 10 \%$
- FH s ASKVO nebo alespoň jedním dalším velkým
rizikovým faktorem

\begin{tabular}{|c|}
\hline vysoké riziko \\
\hline $\begin{array}{l}\text { - významné zvýšení izolovaného rizikového } \\
\text { faktoru, zejména T-C }>8 \mathrm{mmol} / \mathrm{l} \text {, } \\
\mathrm{LDL}-\mathrm{C}>4,9 \mathrm{mmol} / \mathrm{l} \text { nebo } \mathrm{TK} \geq 180 / 110 \mathrm{~mm} \mathrm{Hg} \\
\text { - pacienti s } \mathrm{FH} \text { bez dalších velkých rizikových } \\
\text { faktorů } \\
\text { - pacienti s DM bez orgánového poškození, } \\
\text { s dobou trvání } \mathrm{DM} \geq 10 \text { let nebo s dalším } \\
\text { rizikovým faktorem } \\
\text { - CKD } 2 \text {. a } 3 \text {. stupně } \\
\text { (eGFR }>0,5 \text { a }<1,0 \mathrm{ml} / \mathrm{s} / 1,73 \mathrm{~m}^{2} \text { ) } \\
\text { - vypočtené riziko fatální KV-přihody pomocí } \\
\text { SCORE } \geq 5 \% \text { a }<10 \%\end{array}$ \\
\hline
\end{tabular}

\section{nízké riziko}

- vypočtené riziko fatální KV-príhody pomocí mladi pacienti (s DM1T do věku) s trváním diabetu $<10$ let, $\quad \mathrm{SCORE}<1 \%$ bez dalších rizikových faktorů vypočtené riziko fatální KV-příhody pomocí SCORE $\geq 1 \%$ a $<5 \%$

ASKVO - aterosklerotické kardiovaskulární onemocnění AKS - akutní koronární syndrom TK - krevní tlak CABG - coronary artery bypass graft/aortokoronární bypass CKD - chronic kidney disease/chronické onemocnění ledvin CT - computed tomography/výpočetní tomografie KVO - kardiovaskulární onemocnění DM - diabetes mellitus eGFR - estimated glomerular filtration rate/odhadovaná glomerulární filtrace) FH - familiární hypercholesterolemie LDL-C - low-density lipoprotein cholesterol IM -infarkt myokardu PCI - perkutánní koronární intervence SCORE - Systematic Coronary Risk Estimation T-C - celkový cholesterol TIA - transitorní ischemická ataka 
a non-HDL-C. S ohledem na kumulaci nových dokladů z intervenčních studií se opět významně posunují doporučené cílové hodnoty ve všech rizikových kategoriích kromě osob s nízkým rizikem, které zůstávají beze změn. Jejich přehled uvádí tab. 2.

Nově doporučení postulují požadavek nejen na dosažení určité cílové koncentrace LDL-C, ale také potřebu minimálně $50 \%$ snížení ve srovnání s hladinou před léčbou. Další snížení cílových hodnot zohledňuje skutečnost, že všechny dosavadní intervenční studie zaměřené na snižování LDL-C ukázaly prímý vztah mezi dosaženou hladinou LDL-C a poklesem cévního rizika bez ohledu na vstupní koncentraci LDL-C (tedy princip „čím níže, tím lépe").

Snížení cílových hodnot vždy vyvolává diskuse, a proto považujeme za účelné shrnout nejdůležitější důkazy shromážděné od publikace předchozí verze doporučených postupů, které představují základní „důkazní materiál“ podporující nové cíle léčby (tab. 3).

Sekundárním cílem zejména u osob $\mathrm{s}$ hypertriglyceridemií je non-HDL-C, jehož cílová hodnota je o 0,8 mmol/l vyšší než doporučený cíl pro LDL-C v dané rizikové kategorii. Podobně používáme i sledování hodnoty apoB, jehož koncentrace u velmi vysoce rizikových osob má být snížena na hodnotu $<0,65 \mathrm{~g} / \mathrm{l}$, v kategorii vysokého rizika $<0,8 \mathrm{~g} / \mathrm{l}$ a u osob se středně zvýšeným rizikem $<1,0 \mathrm{~g} / \mathrm{l}$. Hladiny triglyceridů $>1,7 \mathrm{mmol} / \mathrm{l}$ a koncentrace $\mathrm{HDL}-\mathrm{C}<1,0 \mathrm{mmol} / \mathrm{l}$ u mužů a $<1,2 \mathrm{mmol} / \mathrm{l}$ u žen jsou sice dále považovány za důležité modulátory rizika, ne však za léčebné cíle. Oba tyto parametry uspokojivě zohledňuje cílová hodnota non-HDL-C či apolipoproteinu B.

Tab. 4 shrnuje změny cílových hodnot oproti doporučeným postupům z roku 2016.

Navíc u nemocných s rekurentní aterotrombotickou příhodou do dvou let od první události při terapii maximální tolerovanou dávkou statinu a ezetimibem je doporučeno snížení LDL-C $<1,0 \mathrm{mmol} / \mathrm{l}$.

Všechny posuny cílových hodnot vyústí v nutnost používání intenzivní statinové terapie většinou v kombinaci s ezetimibem u širšího spektra nemocných. Nových cílových hodnot bude u některých pacientů možno dosaho-

\section{Tab. 1. Tabulka SCORE pro regiony s vysokým KV-rizikem}

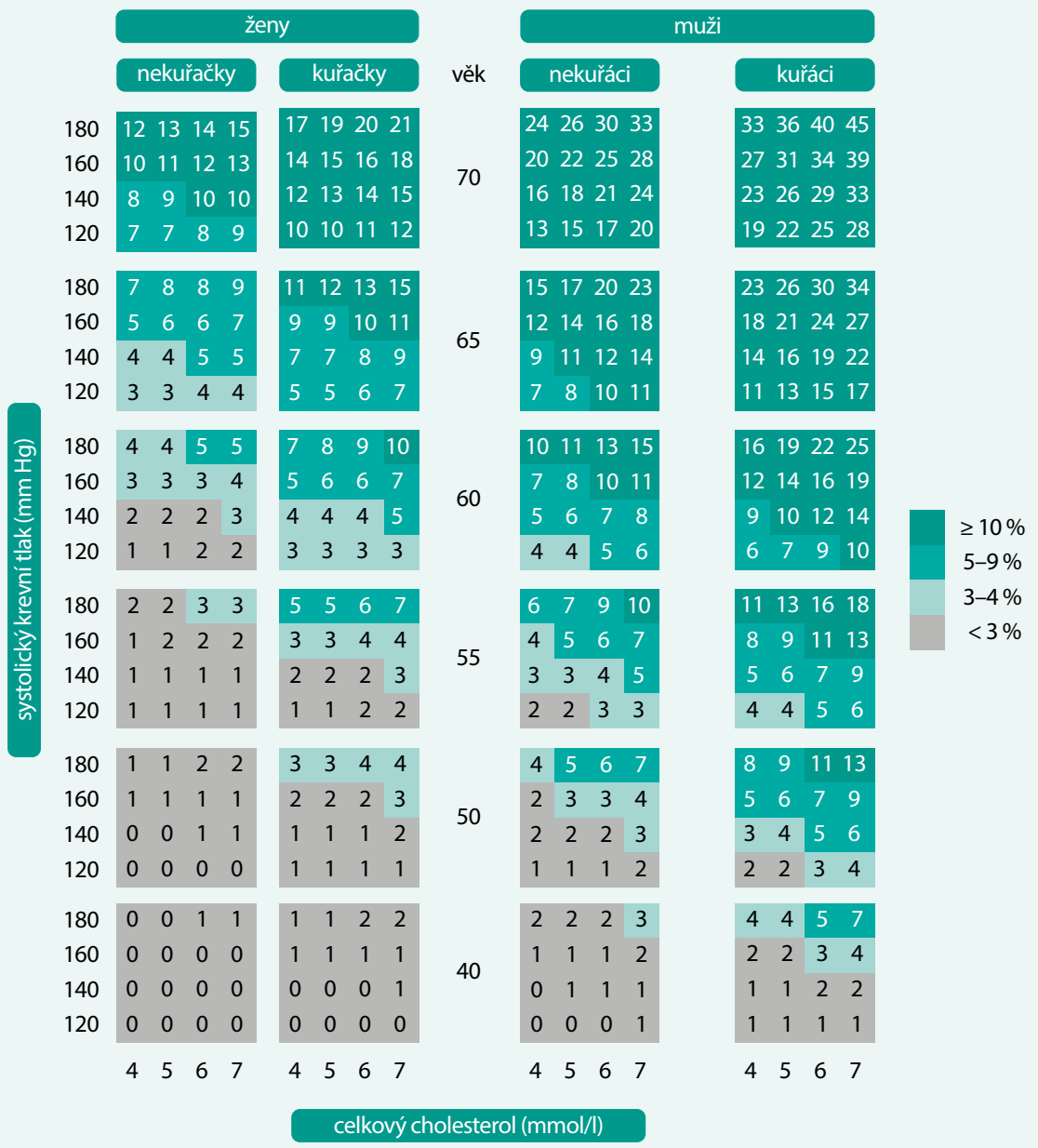


vat pouze při využití nových léčebných možností (např. inhibitory P(SK9).

\section{Změny životního stylu v léčbě DLP (nefarmakologická opatření)}

V oddíle komentovaných doporučených postupů ESC/ EAS věnovaném režimovým opatřením v léčbě DLP nedošlo k zásadním změnám proti předchozí verzi. Nefarmakologická opatření nadále představují základ léčby dyslipidemie i intervence rizika ASKVO. Optimalizace tělesné hmotnosti, nekuřáctví a dostatečná pohybová aktivita jsou stále nejdůležitějšími požadavky. Doporučení ke změně diety mají vycházet z regionálních zvyklostí. Za nejdůležitější z hlediska snížení LDL-C a celkového cholesterolu (Total Cholesterol - T-C) nadále považují autoři doporučených postupů eliminaci konzumace transmastných kyselin a snížení podílu nasycených tuků na $<7 \%$ celkového energetického príjmu a jejich nahrazení ne- nasycenými tuky. Pro snížení triglyceridů je rozhodující redukce nadměrné tělesné hmotnosti a omezení konzumace alkoholu, pro zvýšení HDL-C eliminace transmastných kyselin a zvýšení fyzické aktivity. Střídmá konzumace alkoholu definovaná jako spotřeba $<10 \mathrm{~g}$ alkoholu denně pro muže i ženy není doporučena, ale může být tolerována u osob, které již alkohol konzumují a nemají hypertriglyceridemii. Komentovaná doporučení ESC/ EAS z roku 2019 rozebírají i otázku tzv. funkčních potravin neboli nutraceutik se zvláštním vlivem na hladiny krevních lipoproteinů a možným př́znivým efektem na lipidogram i riziko ASKVO (např. polikosanol, rostlinné steroly, omega-3 mastné kyseliny, berberin, extrakt $z$ červené fermentované rýže a další). Fytosteroly a extrakty z červené fermentované rýže obsahující monakolin K mohou být zváženy u osob nedosahujících cílové hodnoty LDL-C při režimových opatřeních za předpokladu, že se nekvalifikují pro farmakoterapii statinem.

\section{Tab. 2. Cílové hodnoty LDL-C, non-HDL-C a apoB}

\begin{tabular}{|c|c|c|c|c|c|}
\hline riziko & nízké & středně zvýšené & vysoké & velmi vysoké & extrémní* \\
\hline LDL-C (mmol/l) & $<3,0$ & $\begin{array}{l}<2,6 \text { a snížení nejméně } \\
\text { o } 50 \text { \% hodnoty před léčbou }\end{array}$ & $\begin{array}{l}<1,8 \text { a snížení nejméně } \\
\text { o } 50 \% \text { hodnoty před léčbou }\end{array}$ & $\begin{array}{l}<1,4 \text { a snížení nejméně } \\
\text { o } 50 \% \text { hodnoty před léčbou }\end{array}$ & $<1,0$ \\
\hline non-HDL-C (mmol/l) & $<3,8$ & $<3,4$ & $<2,6$ & $<2,2$ & $<1,8$ \\
\hline аров (g/l) & - & $<1$ & $<0,8$ & $<0,65$ & $<0,55$ \\
\hline
\end{tabular}

\begin{tabular}{|c|c|c|c|}
\hline studie & $\begin{array}{l}\text { dosažené koncentrace } \\
\text { LDL-C placebo vs ak- } \\
\text { tivní léčba (mmol/l) }\end{array}$ & sledované ukazatele & $\begin{array}{c}\text { RR ( } 95 \% \text { IS) } \\
\text { při snížení LDL-C } \\
\text { o } 1 \mathrm{mmol} / \mathrm{l}\end{array}$ \\
\hline $\begin{array}{l}\text { CTT metaanalýza (vysoce intenzivní vs standardní statin; } \\
\text { subpopulace }<2,0 \mathrm{mmol} / \mathrm{l} \text { ) [12] }\end{array}$ & 1,71 vs 1,32 & $\begin{array}{l}\text { IM, úmrtí z koronárních příčin, } \\
\text { CMP, koronární revaskularizace }\end{array}$ & $0,71(0,56-0,91)$ \\
\hline IMPROVE-IT2 (ezetimib plus statin vs statin) [13] & 1,80 vs 1,40 & $\begin{array}{l}\mathrm{KV} \text { úmrtí, IM, CMP, nestabilní } \mathrm{AP} \text {, } \\
\text { koronární revaskularizace }\end{array}$ & $0,94(0,89-0,99)$ \\
\hline $\begin{array}{l}\text { FOURIER3 (evolokumab plus vysoká dávka statinu } \pm \text { ezeti- } \\
\text { mib vs vysoká dávka statinu } \pm \text { ezetimib) }[14]\end{array}$ & 2,37 vs 0,78 & $\begin{array}{l}\text { KV úmrtí, IM, CMP, nestabilní AP, } \\
\text { koronární revaskularizace }\end{array}$ & $0,85(0,79-0,92)$ \\
\hline $\begin{array}{l}\text { ODYSSEY OUTCOMES4 (alirokumab plus vysoká dávka } \\
\text { statinu } \pm \text { ezetimib vs vysoká dávka statinu } \pm \text { ezetimib) [15] }\end{array}$ & 2,61 vs 1,37 & $\begin{array}{l}\text { IM, úmrtí z koronárních příčin, } \\
\text { CMP, nestabilní AP }\end{array}$ & $0,85(0,78-0,93)$ \\
\hline
\end{tabular}

AP - angina pectoris CMP - cévní mozková př́hoda IM - infarkt myokardu IS - interval spolehlivosti KV - kardiovaskulární RR - relativní riziko

\begin{tabular}{|c|c|c|}
\hline \multirow{2}{*}{ kategorie rizika } & \multicolumn{2}{|c|}{ LDL-cíl } \\
\hline & 2016 & 2019 \\
\hline velmi vysoké riziko & $\begin{array}{l}<1,8 \mathrm{mmol} / \mathrm{l} \\
\text { nebo } \\
>50 \% \text { snížení, pokud je LDL-C 1,8-3,5 mmol// }\end{array}$ & $<1,4 \mathrm{mmol} / \mathrm{l}$ a $>50 \%$ snížení \\
\hline vysoké riziko & $\begin{array}{l}<2,6 \mathrm{mmol} / \mathrm{l} \\
\text { nebo } \\
>50 \% \text { snížení, pokud je LDL-C 2,6-5,2 mmol/l }\end{array}$ & $<1,8 \mathrm{mmol} / \mathrm{l}$ a $>50 \%$ snížení \\
\hline střední riziko & $<3,0 \mathrm{mmol} / \mathrm{l}$ & $<2,6 \mathrm{mmol} / \mathrm{l}$ \\
\hline nízké riziko & $<3,0 \mathrm{mmol} / \mathrm{l}$ & $<3,0 \mathrm{mmol} / \mathrm{l}$ \\
\hline
\end{tabular}




\section{Farmakoterapie dyslipidemií}

Hlavní farmakoterapeutické postupy v léčbě DLP se nemění. Statiny nadále představují léčbu volby u osob se zvýšeným rizikem ASKVO a zvýšenou koncentrací LDL-C či dalších aterogenních lipoproteinů. Doporučené postupy zdůrazňují nutnost individualizace léčby, titrace dávky k dosažení léčebných cílů a vhodnost kombinace, není-li možné maximální tolerovanou dávkou statinu cílových hodnot dosáhnout.

Sekvestranty žlučových kyselin (pryskyřice) své místo $v$ doporučených postupech mají nadále, přestože v klinické praxi $v$ našich podmínkách se $s$ nimi setkáváme velmi omezeně. Hlavní limit použití představuje gastrointestinální intolerance. Pryskyřice mají však nadále své místo $v$ léčbě zejména $u$ osob se statinovou intolerancí či u pacientů nedosahujících cílových hodnot LDL-C při další léčbě, prípadně u žen s familiární hypercholesterolemií v období těhotenství a laktace. Nejvýhodnější (a nejlépe tolerované) jsou vysoce polymerní pryskyřice (kolesevelam), v ČR je aktuálně dostupný pouze cholestyramin.

Inhibitory vstřebávání cholesterolu reprezentované nadále jediným zástupcem této třídy ezetimibem se od vydání předchozí verze doporučených postupů dočkaly dalších dokladů opravňujících novou formulaci doporučení k jeho použití. Nově guidelines uvádějí, že ezetimib je doporučen do kombinace u pacientů nedosahujících cílové hodnoty LDL-C při maximální/maximálně tolerované dávce statinu. Doporučení rekapitulují příznivý bezpečnostní profil, jednoduchost léčby (uniformní dávkování, nezávislost na denní době či přijmu potravy), navíc v poslední době podpořená dostupností fixních kombinací se statiny.

Inhibitory proprotein konvertázy subtilizin-kexin 9 (PCSK9i), monoklonální protilátky specificky blokující interakci tohoto proteinu s LDL-receptorem, dostávají v guidelines verze 2019 vyšší úroveň doporučení. Alirokumab a evolokumab mají být zváženy, pokud nelze dosáhnout stanovených cílových hodnot prì použití maximálně tolerované dávky statinu v kombinaci s ezetimibem. Použití v klinické praxi v Česku se řídí nejen doporučeními odborných společností, ale významně jej ovlivňují i podmínky úhrady stanovené Státním ústavem pro kontrolu léčiv. $V$ detailu odkazujeme na publikované dokumenty $\mathrm{k}$ tomuto tématu $[4,5]$.

$\checkmark$ dalším textu uvedeme $v$ přehledu s využitím tabulek $z$ textu doporučení ESC/EAS k managementu DLP z roku 2019 hlavní principy farmakologických možností ovlivnění jednotlivých poruch metabolizmu sérových lipidů a lipoproteinů.

\section{Farmakoterapie hypercholesterolemie}

Základní volby farmakologické léčby $k$ ovlivnění hypercholesterolemie zůstávají neměnné. Účinné statiny titrované k dosažení cílové hodnoty LDL-C představují základní stupeň farmakoterapie, k níž přidáváme ezetimib, př́padně PCSK9 inhibitor. Algoritmus snižování LDL-C uvádí schéma 2.

\section{Farmakoterapie hypertriglyceridemie}

Nadále rozlišujeme dvě hlavní klinické indikace ke snižování hladin triglyceridů. U významné hypertriglyceridemie s hladinami TG $>10 \mathrm{mmol} / \mathrm{l}$ je třeba snižením hladin omezit riziko akutní pankreatitidy. Přes nesporně zásadní roli nefarmakologického př́stupu při léčbě této dyslipidemie je léčivem první volby v této situaci fenofibrát, případně v kombinaci s vysokými dávkami (3-4 g denně) omega-3 mastných kyselin. Ty se nově objevují $v$ doporučeních pro management hypertriglyceridemie $u$ (velmi) vysoce rizikových, protože derivát eikosapentaenové kyseliny (ikosapent ethyl) v dávce $4 \mathrm{~g}$ denně ve studii REDUCE-IT přinesl další významné snížení rizika právě u takových pacientů.

Farmakologická léčba mírně a středně zvýšených hladin triglyceridů do $10 \mathrm{mmol} / \mathrm{l}$ má být zvážena v kontextu vysokého a velmi vysokého rizika. Lékem volby jsou statiny. V príl-

Schéma 2. Terapeutický algoritmus pro snižováni LDL-C. Upraveno podle [1]

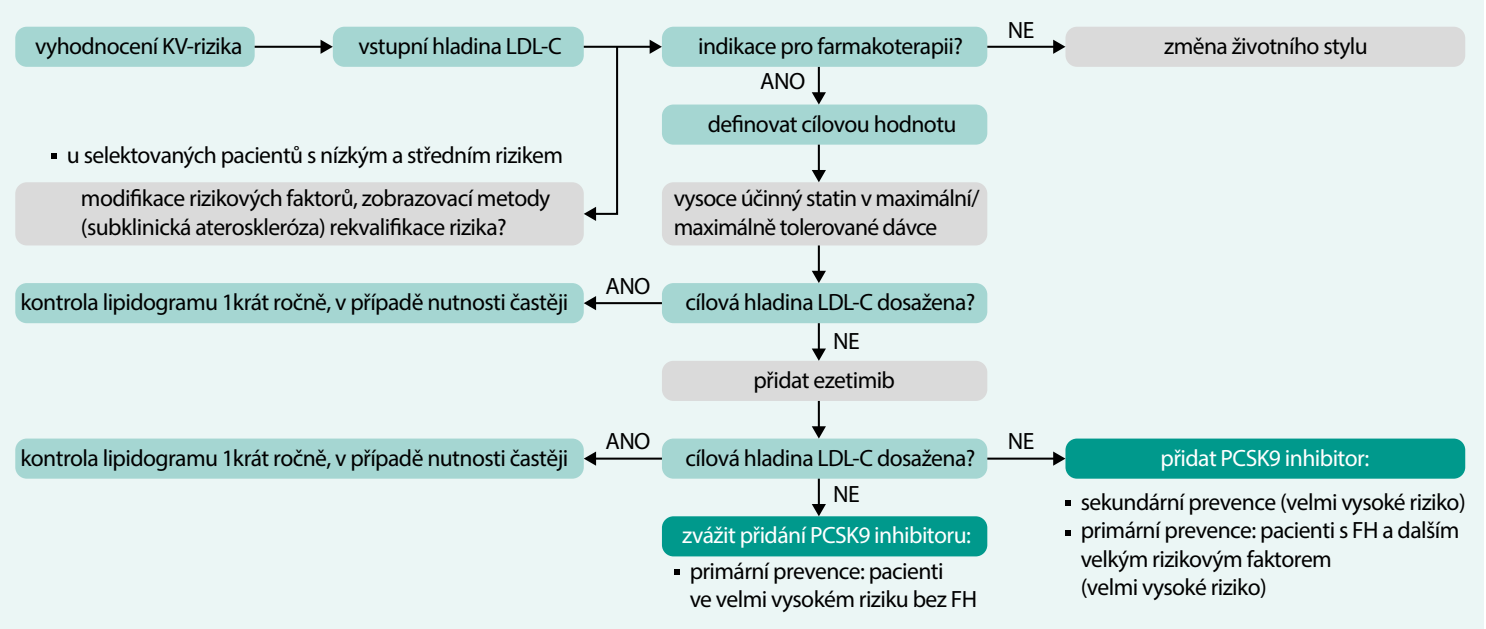


padě trvající elevace triglyceridů s hodnotami $>2,3 \mathrm{mmol} / \mathrm{l}$ Ize zvážit jejich kombinaci s fenofibrátem.

\section{Doporučení pro farmakoterapii}

hypertriglyceridemie

- u vysoce rizikových nemocných s hypertriglyceridemií > 2,3 mmol/I lze jako lék první volby ke snížení rizika ASKVO zvolit statin

- u vysoce a velmi vysoce rizikových nemocných s TG 1,5-5,6 mmol/l i při léčbě statiny by mělo být zváženo přidání omega-3 mastných kyselin (ikosapent ethyl $2 \times 2$ g denně)

- u osob s přetrvávající hladinou TAG > 2,3 mmol// při dosažení LDL-C cíle může být zváženo přidání fenofibrátu k zavedené terapii statinem

Na rozdíl od verze doporučených postupů ESC/EAS 2016 nenajdeme v aktuálních guidelines specifický odstavec o léčbě zaměřené na zvyšování hladin HDL-C. Randomizované studie $s$ inhibitory CETP (které zvyšuji hladiny HDL-C až 2násobně) nepřinesly očekávané přídatné snížení rizika ASKVO a nebudou uvedeny do klinického použití. Další úrovně důkazů z epidemiologických a mendeliánských randomizačních studií rovněž nepodporují koncept zvyšování HDL-C jako směr k další redukci rizika ASKVO.

\section{Léčba DLP ve specificlicých slkupinách pacientů} Oddíl doporučených postupů ESC/EAS věnovaný vyjmenovaným populačním skupinám se zásadně nezměnil. Přibyly některé důkazy pro určité subpopulace, které umožnily posun třídy doporučení. Pro přehlednost a stručnost uvedeme $v$ tomto Stanovisku pouze tabelovaná shrnutí k jednotlivým pacientským skupinám se zaměřením na odlišnosti od poslední verze doporučení z roku 2016.

\section{Familiární dyslipidemie}

Tento oddíl doporučených postupů pojednává o nejčastějších dobře definovaných formách familiárních dyslipidemií. Největší prostor se dostává familiární hypercholesterolemii, jejíž diagnostiku a vedení léčby shrnujeme níže.

\section{Doporučení pro vyhledávání a léčbu}

\section{pacientů s heterozygotní formou familiární} hypercholesterolemie

- Na FH bychom měli myslet u pacientů s ICHS vzniklou u mužů mladších 55 let a žen mladších 60 let, u osob, u jejichž příbuzných se KVO manifestovalo předčasně, nebo u jejichž príbuzných se objevily šlachové xantomy, a u osob s velmi zvýšeným LDL-C (u dospělých $>5 \mathrm{mmol} / \mathrm{l}$, u dětí $>4 \mathrm{mmol} / \mathrm{l})$.

- Je doporučeno potvrdit diagnózu FH klinickými kritérii, a pokud je to možné, také diagnostikou DNA.

- Pokud je diagnostikován první prípad v rodině, je doporučen kaskádový rodinný screening.

- Je doporučeno, aby pacienti s FH a dokumentovaným ASKVO nebo s alespoň jedním dalším velkým ri- zikovým faktorem byli léčeni jako velmi vysoce rizikoví a ostatní jako vysoce rizikoví.

- Cílovými hodnotami pro léčbu nemocných s FH ve velmi vysokém riziku je $\mathrm{LDL}-\mathrm{C}<1,4 \mathrm{mmol} / \mathrm{l}$ a současně snížení koncentrace LDL-C nejméně o $50 \%$. Pokud není možno dosáhnout cílových hodnot, je třeba snažit se o maximální snížení LDL-C pomocí vhodných lékových kombinací.

- Léčba pomocí PCSK9 inhibitorů je doporučena u velmi vysoce rizikových pacientů s FH, u nichž léčba maximální tolerovanou dávkou statinu s ezetimibem nevedla k dosažení cílové hodnoty LDL-C.

- U dětí je doporučeno vyšetřování od věku 5 let, nebo při suspektní homozygotní formě $\mathrm{FH}$ i dříve.

- Děti s FH by měly být podrobně poučeny o nutnosti dodržovat vhodnou dietu a léčeny statiny od věku 8-10 let. Cílovými hodnotami pro léčbu dětí ve věku nad 10 let je $L D L-C<3,5 \mathrm{mmol} / \mathrm{l}$.

Diagnostice a léčbě pacientů s familiární hypercholesterolemií se věnují samostatné dokumenty pro dospělé i dětské pacienty s FH vypracované ČSAT $[7,8]$. Familiární hypercholesterolemie představuje také jedinou situaci, v níž v dětském věku rutinně indikujeme hypolipidemickou farmakoterapii. Ta by měla být vždy vedena zkušeným specialistou, v České republice je možné využít sít pediatrických pracovišt' projektu MedPed (seznam na <www.athero.cz>). Centra projektu MedPed slouží i ke konzultacím diagnostiky a léčby pacientů s familiárními dyslipidemiemi.

\section{Ženská populace}

Pro léčbu DLP u žen platí stejná pravidla jako u mužů. Doporučené postupy nadále podporují stejné principy léčby u žen jako u mužů, přestože zejména ve starších studiích nebylo zastoupení ženského pohlaví vždy dostatečné. Výsledky klinických hodnocení ale vyznívají jednoznačně a benefit hypolipidemických intervencí u žen považujeme za prokázaný. Je možné a pravděpodobné, že v další verzi doporučených postupů nebude populace žen vyjmenována mezi specifickými subpopulacemi; nesprávná interpretace nižšího rizika ASKVO u žen do věku cca 55-60 let jako známky "celoživotní ochrany" snad z praxe již nyní mizí.

\section{Léčba dyslipidemie u žen}

- V primární prevenci ASKVO je u žen s vysokým rizikem doporučena léčba statiny.

- V sekundární prevenci ASKVO jsou u žen doporučeny stejné indikace a cílové hodnoty jako u mužů.

- Hypolipidemika by neměla být podávána ženám plánujícím těhotenství, během těhotenství a během kojení. U pacientů s těžkou FH Ize však zvážit podávání sekvestrantů žlučových kyselin, které se nevstřebávají z trávicího ústrojí, nebo LDL-aferézu.

\section{Pacienti vyššího věku}

Guidelines ESC/EAS 2019 definují tuto skupinu věkem > 65 let. Od publikace přechozích doporučení máme 
k dispozici některé nové epidemiologické studie i souhrnné metaanalýzy sledující nemocné vyššího věku. Připomeňme, že více než $80 \%$ zemřelých na ASKVO je ve věkové kategorii > 65 let. $V$ souvislosti s prodlužující se délkou života se významně zvyšuje počet osob s IM ve věku > 85 let. Konečně, absolutní riziko pacientů vyššího věku je větší, a proto léčba přináší větší absolutní benefit. $Z$ těchto důvodů nacházíme $v$ guidelines jednoznačnější doporučení k vedení hypolipidemické terapie v nejvyšších třídách.

\section{Doporučení pro léčbu dyslipidemií u osob}

staršich 65 let

- Léčba statiny je u starších nemocných se známým ASKVO doporučena stejně jako u mladších pacientů.

- Je doporučeno, aby léčba statiny byla zahajována nízkou dávkou u osob s poklesem renálních funkcí nebo v případě možných lékových interakcí. Léčba má být titrována $\mathrm{k}$ dosažení cíle LDL-C podle stejných principů jako u mladších osob.

- Léčbu statiny je indikována u osob v primární prevenci podle kategorie rizika u osob mladších 75 let.

- Léčbu statiny je možné zvážit u osob v primární prevenci u osob starších 75let v kontextu vysokého nebo velmi vysokého $\mathrm{KV}$-rizika.

\section{Pacienti s diabetes mellitus}

Pacienti s DM 1. a 2. typu (DM1T, DM2T) mají zvýšené riziko ASKVO. I proto je farmakologická léčba DLP zpravidla nezbytná. Její principy se nemění.

\section{Doporučení pro léčbu dyslipidemie u diabetes} mellitus

- U pacientů s DM2T ve velmi vysokém riziku je doporučeno snížení koncentrace LDL-C nejméně o $50 \%$ a současně dosažení cílové hodnoty LDL-C $<1,4 \mathrm{mmol} / \mathrm{l}$.

- U pacientů s DM2T ve vysokém riziku je doporučeno snížení koncentrace LDL-C nejméně o $50 \%$ a současně dosažení cílové hodnoty LDL-C < 1,8 mmol/l.

- Statiny jsou doporučeny u pacientů s DM1T ve vysokém nebo velmi vysokém riziku.

- Před zahájením kombinačních hypolipidemických režimů je doporučeno intenzifikovat terapii statinem.

- Není-li dosaženo cílové koncentrace LDL-C, měla by být zvážena kombinace statinu s ezetimibem.

- Terapie statinem může být zvážena u pacientů s DM1T i DM2T ve věku > 30 let se známkami orgánového postižení a hladinami LDL-C > 2, $5 \mathrm{mmol} / \mathrm{l}$, za předpokladu, že není plánována gravidita.

Aktuální verze guidelines zdůrazňuje specifika dyslipidemie vznikající v kontextu inzulinové rezistence (zmnožení na triglyceridy bohatých a vysoce aterogenních lipoproteinových částic, snížení koncentrací HDL-C, změny postprandiálního metabolizmu lipoporoteinů). Proto je DLP provázející diabetes, prediabetes a metabolický syndrom zvláště významným faktorem negativně ovlivňujícím riziko ASKVO. I u pacientů s DM1T se zvyšuje prevalence metabolického syndromu s negativním dopadem na KV-prognózu nemocných. Navíc díky zlepšené péči se více nemocných s DM1T dožívá vyššího věku, v němž stoupá i význam ASKVO.

\section{Pacienti po akutním koronárním syndromu a podstupující perkutánní koronární revaskularizaci}

Nemocní po akutním koronárním syndromu (AKS) jsou ohroženi jeho recidivou a mají velmi vysoké riziko aterotrombotické komplikace i v jiném povodí. Proto zasluhují maximální pozornost a intenzitu léčby dyslipidemie. Zásadní principy prístupu $\mathrm{k}$ pacientům se nezměnily, a proto můžeme nadále odkazovat na dokument ČSAT ve spolupráci s Pracovní skupinou akutní a intervenční kardiologie ČKS z roku 2012 [9]. Nově celkový přístup k nemocným po prodělané akutní koronární príhodě shrnuje dokument vypracovaný skupinou expertů zastupujících české odborné společnosti [10].

Skupina nemocných s anamnézou AKS byla v poslední době intenzivně zkoumána a data získaná ve studiích zařazujících tyto pacienty umožnila lepší pochopení významu rychlého a intenzivního snižování aterogenních lipoproteinů po AKS. Poslední takovou práci představuje studie EVOPACS s evolokumabem nasazovaným u pacientů do 72 hod po AKS za hospitalizace (téměř dvě třetiny ze zařazených dostali studijní léčbu do 24 hod od manifestace AKS). Dle očekávání byly splněny primární lipidové sledované cíle (významně výraznější pokles LDL-C ve větvi statin + evolokumab ve srovnání s větví statin + placebo) Zajímavější data můžeme očekávat od zobrazovacích podstudií dokumentovaných pokročilými zobrazovacími metodami, které by měly ukázat, jaký vliv na složení aterosklerotických lézí akutní výrazné snížení hladin aterogenních lipoproteinů má [11].

\section{Doporučení pro hypolipidemickou léčbu}

u pacientů s velmi vysokým rizikem a AKS

- U všech nemocných s AKS je nezávisle na vstupních hodnotách LDL-C doporučeno brzy po přijetí zahájit léčbu vysokými dávkami statinu, nebo v ní dále pokračovat, pokud nejsou kontraindikace nebo anamnéza intolerance.

- Koncentrace lipidů by měly být vyšetřeny znovu za 4-6 týdnů po AKS k ověření, zda bylo dosaženo cílových hodnot LDL-C $<1,4 \mathrm{mmol} / \mathrm{l}$ a současně snížení alespoň o 50 \% a zda se neobjevily nežádoucí účinky. Dávka hypolipidemik by měla být upravena dle výsledku.

- Pokud není dosaženo maximálními tolerovatelnými dávkami statinu během 4-6 týdnů cílových hodnot LDL-C, je indikována kombinace s ezetimibem.

- Pokud není dosaženo maximálními tolerovatelnými dávkami statinu $v$ kombinaci $s$ ezetimibem během 4-6 týdnů cílových hodnot LDL-C, je doporučeno zahájit léčbu inhibitory PCSK9.

- U pacientů s prokázanou statinovou intolerancí nebo kontraindikací statinů by měla být zvážena terapie ezetimibem. 
- U pacientů, u nichž není dosaženo kontroly LDL-C maximální tolerovanou dávkou statinu a ezetimibem a vznikne u nich AKS, má být zvážena časná indikace PCSK9 ihibitoru, je-li to možné, ještě za hospitalizace.

- U pacientů podstupujících elektivní $\mathrm{PCI}$ nebo $\mathrm{PCI}$ v kontextu AKS by mělo být zváženo podání vysoké dávky statinu.

\section{Pacienti s anamnézou ischemické cévní mozkové příhody}

Doporučení ESC/EAS 2019 pro management dyslipidemií se poprvé v samostatném odstavci vyjadřují k oblasti hypolipidemické intervence u nemocných s anamnézou ischemického iktu. Připomínají, že ischemická CMP má různé příčiny, $z$ nichž řada nesouvisí s aterotrombózou. Na druhou stranu pacienti s anamnézou ischemického iktu mají obecně velmi vysoké riziko aterotrombotické př́hody - at' už v podobě rekurentní cerebrovaskulární príhody nebo postižení jiného povodí. Guidelines rovněž konstatují možnost mírného navýšení rizika hemoragické $C M P$ u uživatelů statinů. $V$ této souvislosti dodejme, že toto riziko je malé a vyvažuje jej př́nos v podobě snižení výskytu ischemických príhod. Navíc evidence dokládající souvislost $s$ terapií statiny a krvácivým iktem není jednoznačná.

\section{Doporučení pro hypolipidemickou terapii u pacientů po prodělané ischemické CMP \\ - Pacienti s anamnézou ischemické CMP nebo tranzi- torní ischemické ataky mají velmi vysoké riziko ASKVO (zejména rekurentní CMP), a proto je doporučena in- tenzivní hypolipidemická terapie ke snížení LDL-C.}

\section{Pacienti se srdečním selháním a chlopenními vadami}

Neutrální výsledky klinických studií se statiny u pacientů se srdečním selháním či aortální stenózou vedla $k$ doporučení nezahajovat $u$ těchto pacientů farmakoterapii hypolipidemiky. Připomeňme však, že léčba statiny je u těchto skupin nemocných bezpečná a existuje-li nějaká další indikace pro jejich podání, má být léčba vedena se stejnými principy jako u ostatních osob.

Ani nové studie s PCSK9i nepřinesly nové informace. $V$ některých $z$ nich se sice ukázala možnost asociace mezi osou PCSK9i - LDL-receptor a výskytem aterotrombotických príhod u pacientů se srdečním selháním, ale vliv na průběh srdečního selhání zjištěn nebyl. I u PCSK9i tedy platí, že nejsou indikovány z indikace ovlivnění průběhu srdečního selhání.

Malý benefit podávání omega-3 mastných kyselin $v$ kontextu srdečního selhání nebyl v poslední době dále rozpracován, a proto tuto možnost nová doporučení vypouštějí.

\section{Doporučení pro léčbu dyslipidemií u srdečního selhání nebo chlopenních vad \\ - U nemocných se srdečním selháním není zahájení léčby statiny doporučeno, pokud pro ni není jiná indikace.}

- Hypolipidemická léčba není doporučena u pacientů s aortální stenózou bez anamnézy ASKVO, pokud není pro tuto léčbu jiná indikace.

\section{Pacienti s autoimunitními chorobami}

Autoimunitní onemocnění (revmatoidní artritida, systémový lupus erythematodes, psoriáza), zejména s vystupňovanou zánětlivou aktivitou, nepochybně zvyšuji kardiovaskulární riziko. Heterogenita pacientských populací a absence velkých klinických studií v této oblasti nedovolují formulovat specifická doporučení. Hypolipidemická farmakoterapie má být indikována u těchto pacientů podle jejich aktuálního KV rizika. Samotná přitomnost chronického autoimunitního onemocnění není indikací pro podání hypolipidemik. V tomto oddíle se doporučení nemění proti verzi roku 2016.

\section{Pacienti s chronickým onemocněním ledvin} Chronické renální postižení (Chronic Renal Disease CKD) zvyšuje kardiovaskulární riziko a může alterovat metabolizmus sérových lipidů. Intenzivní pátrání po přítomnosti renálního onemocnění je podmínkou správného stanovení KV-rizika i volby léčebné strategie. Pacienti se středně závažným až závažným poklesem renálních funkcí jsou klasifikováni jako vysoce nebo velmi vysoce cévně rizikoví a intervence DLP u nich musí být vedena k dosažení cílových hodnot LDL-C (ev. non-HDL-C).

\section{Doporučení pro léčbu dyslipidemií u pacientů} se středně těžkým nebo těžkým CKD

- Pacienti s CKD stadia 3 musí být posuzováni jako nemocní s vysokým a nemocní s CKD stadia 4-5 s velmi vysokým rizikem ASKVO.

- Léčba statiny, nebo kombinací statin/ezetimib je indikovaná u těch nemocných s CKD, kteří nejsou zařazeni v dialyzačním programu.

- U dialyzovaných pacientů bez ASKVO by léčba statiny neměla být zahajována.

- U nemocných léčených statiny, nebo kombinací statin/ ezetimib již před zařazením do dialýzy, by se mělo v léčbě pokračovat, zejména pokud tito nemocní mají anamnézu ASKVO.

\section{Pacienti po orgánové transplantaci}

Nemocní po transplantačních výkonech mají zvýšené riziko ASKVO v důsledku primárního onemocnění i nezbytné léčby po transplantaci. Nutnost imunosupresivní a další konkomitantní medikace činí vedení léčby DLP obtížnější; sama tato léčba může alterovat metabolizmus sérových lipoproteinů. Přesto by měla být vyvíjena maximální snaha o dosažení uspokojivé kontroly lipidogramu s využitím hypolipidemické terapie.

\section{Doporučení pro léčbu dyslipidemií}

u transplantovaných nemocných

- U transplantovaných pacientů by měl být jako lék první volby zvážen statin. Léčbu je třeba zahájit nízkými dáv- 
kami a poté opatrně titrovat. Pozornost je třeba věnovat lékovým interakcím, zejména s cyklosporinem.

- U pacientů, kteří netolerují statiny nebo mají stále významnou dyslipidemii a vysoké reziduální riziko i při maximální tolerované dávce statinu, Ize zvážit alternativní nebo kombinovanou léčbu s ezetimibem.

\section{Pacienti s nekoronární aterosklerózou (aterosklerotickým postižením perifernich tepen)}

Nemocní s aterosklerotickým postižením periferních tepen (karotid, abdominální aorty, končetinových tepen, renálních tepen) mají velmi vysoké KV-riziko, a proto management dyslipidemie musí být u těchto pacientů maximálně intenzivní. Po postižení periferních tepen je třeba pátrat u všech pacientů s velmi vysokým rizikem. Principy hypolipidemické intervence se neliší od ostatních skupin v této kategorii rizika, stejné jsou i léčebné cíle. Nově doporučení výslovně uvádějí, že terapie u nemocných s nekoronární aterosklerózou má být vedena maximální tolerovanou dávkou statinu s ezetimibem a prípadně s PCSK9i tak, aby bylo dosaženo cílové hladiny LDL-C.

\section{Pacienti s pozitivitou HIV}

Intervence dyslipidemie poutá v poslední době u HIV pozitivních pacientů stále více pozornosti. Důvodů je několik. Díky moderní léčbě HIV-pozitivní pacienti přežívají podstatně déle, a tak se u nich setkáváme častěji s KV-komplikacemi. Navíc protiinfekční léčba přináší radu metabolických nežádoucích účinků (např. inzulinovou rezistenci). Hypolipidemická léčba má poměrně vysoké riziko nežádoucích lékových interakcí s antiretrovirovými léčivy (inhibitory proteáz). Doporučení uvádějí, že preferovanými statiny by měly být prava-, fluva-, pitava- a rosuvastatin (simva- a lovastatin mají s inhibitory proteáz silnou interakci) a léčba má být vedena za předpokladu pečlivé monitorace pacienta.

\section{Pacienti s psychiatrickými onemocněními}

Ve výčtu specifických pacientských skupin najdeme dále také pacienty s psychiatrickými onemocněními. Guidelines si všímají několika důležitých aspektů: KV-riziko těchto pacientů je často zvýšeno v důsledku vysoké prevalence rizikových faktorů (zejména kouření či abúzu dalších návykových látek, nízké pohybové aktivitě, nevhodné dietě apod), zvýšené míry stresu, metabolických nežádoucích účinků psychofarmakoterapie a v neposlední řadě v důsledku nonadherence $k$ doporučením. V důsledku toho se ASKVO vyskytují u pacientů s psychiatrickou diagnózou přibližně o 10 let dříve než v běžné populaci. I proto je management rizikových faktorů včetně hypolipidemické farmakoterapie u těchto pacientů indikován.

\section{Doporučení pro léčbu hypolipidemiky}

u pacientů s psychiatrickými onemocněními

- Těžká psychiatrická onemocnění modifikují celkové riziko ASKVO.
- Postup ovlivnění KV-rizika u nemocných s psychiatrickými onemocněními se neliší od postupu u pacientů s vysokým a velmi vysokým rizikem ASKVO.

- U pacientů s psychiatrickými onemocněními je třeba věnovat pozornost zejména adherenci k úpravám životního stylu a farmakologické léčbě.

\section{Laboratorní monitorování pacientů léčených hypolipidemiky}

Podobně jako v předchozích verzích doporučených postupů i nyní musíme předeslat, že doporučení pro monitoring pacientů během hypolipidemické léčby vychází z konsenzu expertů, nebot' nemáme k dispozici studie, které by posuzovaly různé vhodné strategie monitorace pacientů. Na druhé straně, tato sekce doporučení nedoznala podstatných změn a vychází z postupů osvědčených klinickou praxí. Na tomto místě je třeba připomenout, že přes nutnou individualizaci sledování pacientů se zohledněním jejich charakteristik (komorbidity, konkomitantní medikace, výskyt nežádoucích účinků apod) se v praxi setkáváme spiše s vyšší četností kontrol a širším panelem rutinně testované „bezpečnostní laboratoře. Připomeňme, že statiny (ale i ezetimib či PCSK9i) mají mimořádně přiznivý bezpečnostní profil a stabilizované pacienty můžeme testovat ne častěji než jednou ročně (tab. 5).

Při nálezu zvýšené hodnoty CK anebo při výskytu myalgií je doporučeno vždy aktivně pátrat po jiné etiologii těchto symptomů. Izolovaný vzestup CK bez myalgií většinou nemívá kauzální souvislost se statiny, častými př́činami bývá např. zvýšená svalová námaha, svalové poranění (včetně např. i.m. injekce), alkohol, virové a bakteriální infekty, endokrinopatie, chronické srdeční onemocnění, přidání jiné medikace (např. kortikoidy, antibiotika, antipsychotika, imunosupresiva a řada dalších). $U$ některých osob může být asymptomatická trvalá (a kolísající) elevace CK bez zjistitelné př́činy. Některé z výše uvedených príičin mohou vést také k myalgiím (virové infekty, alkohol, svalová námaha).

\section{Nálkladová efelktivita prevence kardiovasku- lárnich přihod intervenci dyslipidemie}

V poslední době se do klinického použití dostávají hypolipidemické intervence spojené s vysokýmí náklady na léčbu (např. PCSK9i, lomitapid, anti-sense terapie). Proto se i verze doporučených postupů k managementu dyslipidemií 2019 k této otázce vyjadřuje ve zvláštním a nově zařazeném oddíle. $Z$ originálního textu vybíráme přehled shrnující klíčová fakta k tématu.

Klíčová fakta k nákladové efektivitě prevence KVO hypolipidemickou intervencí

- Prevence KVO změnami životního stylu, léky nebo obojím je nákladově efektivní $v$ mnoha scénářích, včetně populačních prístupů a akcí zaměřených na osoby se zvýšeným rizikem KVO. 
- Nákladová efektivita závisí na několika faktorech, včetně rizika KVO před léčbou a hladinách LDL-C, nákladech na léčbu a využívání preventivních strategií.

- Intervence posilující prevenci KVO jsou nákladově efektivnější u jednotlivců a populací s vyšším rizikem KVO.

- Pro analýzy nákladové efektivity jsou důležité informace o dlouhodobé prognóze onemocnění a účincích léčby; posílení důkazů ke zpřesnění takových údajů se doporučuje.

Přestože je tematika nákladové efektivity velmi důležitá, připomeňme, že zhodnocení tohoto parametru vyžaduje (často chybějící) vstupní informace o dlouhodobé prognóze onemocnění v různých stadiích vývoje, a také data o dlouhodobém efektu terapií. Modelování používané pro analýzy nákladové efektivity je náročné a často se dynamicky mění $v$ souvislosti se změnami cen i dalších údajů tvořících vstupy takových analýz. Zásadně nelze přenášet výsledky nákladových analýz z prostředí jednoho zdravotního systému do jiného; vždy musíme pracovat s regionálně specifickými daty.

\section{Adherence k režimovým \\ i farmakoterapeutickým postupům}

V poslední kapitole doporučení pro management dyslipidemií ESC/EAS 2019 najedeme stat' věnovanou adherenci. S ohledem na fakt, že hypolipidemické intervence patří mezi preventivní strategie, jejichž efekt Ize hodnotit s odstupem (někdy i desítek) let, představuje adherence $v$ této oblasti jeden ze zásadních faktorů, jimž je třeba věnovat pozornost v každodenní praxi.

\section{Nejdůležitější pravidla pro zvýšení adherence}

- Prozkoumejte motivaci a identifikujte ambivalenci. Zvažte klady a zápory. Změny: posud'te a posilujte soběstačnost a sebedůvěru; vyhněte se kruhovým diskusím.

- Nabídněte podporu a navažte vztah s pacientem a jeho/ její rodinou.

- Zapojte partnera, ostatní členy domácnosti nebo pečovatele, kteří mohou ovlivňovat životní styl pacienta.

- Použijte metodu OARS (otevřené otázky, potvrzení, reflektivní poslech, shrnutí při diskusi o změnách chování <www.smartrecovery.org/wp-content/uploads/ 2017/03/UsingMlinSR.pdf>).

- Přizpůsobte rady individuální kultuře pacienta, jeho zvyklostem a situaci.

- Použijte nastavení cílů metodou SMART (vyjednat cíle změn, které jsou specifické, měřitelné, dosažitelné, realistické a termínované). Sledujte dosahování cílů a zaznamenejte pokrok na sdíleném záznamu.

Je jisté, že důraz na dosažení dobré a dlouhodobé adherence nemocných $\mathrm{k}$ léčebným opatřením zásadním způsobem ovlivňuje efektivitu léčby i prognózu nemocných.
Shrnuti hlavnich myšlenek doporučeni pro management DLP ESC/EAS verze 2019

1. Cholesterol a riziko. Prospektivní, randomizované a mendeliánské randomizační studie ukázaly, že vysoká hladina LDL-C je příčinou ASKVO. V celém rozsahu koncentrací LDL-C platí princip "čím níže, tím lépe", přinejmenším do úrovně $1 \mathrm{mmol} / \mathrm{l}$. Snížení rizika ASKVO dosažitelné redukcí LDL-C (např. statinem, ezetimibem nebo PCSK9i) závisí na absolutním snížení LDL-C, přičemž každá redukce o $1 \mathrm{mmol} / \mathrm{l}$ odpovídá poklesu rizika ASKVO asi o pětinu.

2. PCSK9i. Velké studie ukázaly, že PCSK9i dále snižují riziko ASKVO, pokud jsou přidávány $k$ terapii založené na statinu. Jejich použití zatím zůstává omezeno na pacienty v nejvyšším riziku ASKVO.

3. Použití zobrazovacích metod pro stratifikaci rizika. Stanovení kalciového skóre koronárních tepen (CAC-skóre) pomocí CT může být užitečné při rozhodování o léčbě u nemocných ve středním riziku ASKVO. Výsledek CAC-skóre může být užitečný při diskusi s pacientem, který nedosahuje cílové hodnoty LDL-C při režimových opatřeních a je zvažována farmakologická léčba. Podobně lze využít dokumentaci jednoznačného aterosklerotického plátu při ultrasonografickém vyšetření karotid nebo femorálních tepen.

4. Použití apolipoproteinu B při stratifikaci rizika. Apolipoprotein $B$ může být lepším ukazatelem expozice jednotlivce aterogenním lipoproteinům, a proto může být jeho použití zvláště užitečné při posuzování rizika u osob, u kterých měření LDL-C vede $k$ podcenění tohoto rizika (osoby s vysokými TAG, DM, obezitou nebo velmi nízkou koncentrací LDL-C).

5. Použití lipoproteinu(a) při stratifikaci rizika. Jednorázové stanovení $L p(a)$ může pomoci identifikovat osoby s velmi vysokou koncentrací Lp(a), které mohou mít značné celoživotní riziko ASKVO. Může být také nápomocný při další stratifikaci rizika u pacientů s vysokým rizikem ASKVO, u pacientů s předčasnou manifestací ASKVO v rodinné anamnéze, a napomoci určit léčebné strategie $u$ osob, u nichž se odhad rizika pohybuje na rozhraní rizikových kategorií. Měl by být vyšetřen u všech osob alespoň 1 krát v životě.

6. Zpřísnění léčebných cílů. Základním požadavkem u pacientů s nejvyšším rizikem zůstává co největší možné snížení LDL-C. Cílem těchto doporučení je podpořit tento požadavek nastavením minimálního procentního snížení LDL-C (50\%) a současně absolutního cíle léčby $L D L-C<1,4 \mathrm{mmol} u$ velmi vysoce rizikových a $\mathrm{LDL}-\mathrm{C}<1,8 \mathrm{mmol} / \mathrm{l}$ u vysoce rizikových. Je doporučeno, aby pacienti s familiární hypercholesterolemií a manifestním ASKVO nebo aspoň jedním dalším rizikovým faktorem byli léčeni jako velmi vysoce rizikoví a ostatní nemocní s FH jako vysoce rizikoví.

7. Léčba pacientů po prodělaném AKS. Nové randomizované klinické studie podporují strategii intenzifikace terapie snižující LDL-C u velmi vysoce riziko- 
vých pacientů s AKS (akutní infarkt myokardu nebo nestabilní angina pectoris). Není-li dosaženo cílové hodnoty LDL-C po 4-6 týdnech léčby nejvyšší tolerovanou dávkou statinu a ezetimibem, je vhodné přidat PCSK9i.
8. Bezpečnost nízkých koncentrací LDL-C. Nejsou známy žádné nepř́znivé účinky velmi nízkých koncentrací LDL-C (např. < $1 \mathrm{mmol} / \mathrm{l})$.

9. Management statinové „intolerance". Zatímco statiny zřídka způsobí vážné poškození svalů (myopa-

\section{Tab. 5. Doporučeni pro monitoraci hladin lipidů a enzymů pǔi léčbě hypolipidemiky}

\section{monitorace hladin lipidů}

Jak často vyšetřovat hladiny lipidů?

Jak často vyšetřovat lipidy po za-

hájení léčby hypolipidemiky?

Jak často vyšetřovat lipidy po do-

sažení cílových nebo optimálních hodnot?

monitorace jaterních a svalových enzymů

\section{před léčbou}

Jak často rutinně vyšetřovat jaterní testy (ALT) u pacientů užívajících hypolipidemika?

\section{Co dělat, když se zvýší jatern testy u pacienta užívajícího hypolipidemika?}

Jak často vyšetřovat CK u pacientů užívajících hypolipidemika?

Co dělat, když se zvýší CK u pacienta užívajícího hypolipidemika?

U kterých pacientů testovat $\mathrm{HbA}$ nebo glykemii nalačno?

před léčbou:

monitorace: vané léčby před zahájením hypolipidemické léčby provést alespoň 2 měření v intervalu 1-12 týdnů, s výjimkou stavů, v nichž je doporučeno okamžité zahájení léčby (AKS a pacienti s velmi vysokým rizikem)

8 ( \pm 4 ) týdny po zahájení léčby

8 ( \pm 4) týdny po úpravě dávkování až do dosažení cílových hodnot

jednou ročně (pokud nejsou problémy s adherencí k léčbě, nebo jiné důvody pro častější kontroly)

poté již rutinní vyšetřování ALT není během hypolipidemické léčby doporučeno

při léčbě fibráty se doporučuje hladiny ALT sledovat

pokud je $A L T<3 \times$ ULN:

- pokračovat $v$ léčbě

- zkontrolovat jaterní testy za 4-6 týdnů

pokud je $A L T>3 \times$ ULN:

- vysadit hypolipidemika, nebo snížit jejich dávku a znovu zkontrolovat jaterní testy za 4-6 týdnů

- opatrné opětovné nasazení hypolipidemika Ize zvážit po normalizaci ALT

pokud přetrvává zvýšení ALT, je třeba vyloučit jiné možné příčiny

- před zahájením léčby

- pokud je vstupní CK $\geq 4 \times$ ULN, nezahajovat léčbu a znovu zkontrolovat

- rutinní monitorování CK není třeba

- vyšetřit CK, pokud se objeví svalové bolesti

- myslet na možnost myopatie a zvýšení CK u rizikových nemocných, jako jsou senioři, pacienti se současnou léčbou vedoucí k lékovým interakcím, pacienti užívající více léků, pacienti s jaterním nebo renálním onemocněním nebo sportovci

pokud je $\mathrm{CK} \geq 4 \times \mathrm{ULN}$ :

- pokud je CK > $10 \times$ ULN, je třeba přerušit léčbu, zkontrolovat renální funkce a monitorovat hladinu CK každé 2 týdny

- pokud je CK $<10 \times$ ULN a nemocný je asymptomatický, je možno pokračovat v podávání hypolipidemik při monitoraci hladin CK za 2-6 týdnů

- pokud je CK < $10 \times$ ULN a nemocný má obtíže, je třeba přerušit léčbu a monitorovat CK do její normalizace; po normalizaci CK je možno zkusit nasadit nižší dávku statinu

- zvážit možnost přechodného zvýšení CK z jiných důvodů jako např. cvičení

- zvážit možnost myopatie, pokud přetrvává elevace CK

- zvážit podávání kombinované léčby nebo jiného léku po poklesu CK

pokud je $\mathrm{CK}<4 \times$ ULN:

- pokud nejsou svalové obtíže, pokračovat v léčbě statinem (nemocný by měl být poučen, aby ihned oznámil př́p. obtíže; je třeba zkontrolovat (K)

- pokud se objeví svalové bolesti, monitorovat pravidelně příznaky a hodnoty CK

- pokud přetrvávají myalgie, přerušit léčbu statinem a obtíže znovu zhodnotit za 6 týdnů; znovu přehodnotit indikaci k léčbě statinem

- zvážit znovunasazení stejného nebo jiného statinu

- zvážit podávání nižší dávky statinu, nebo podávání obden, nebo 1/2 týdně, nebo podávání kombino-

pravidelné kontroly $\mathrm{HbA}_{1 c}$ by měly být zváženy u osob s vysokým rizikem rozvoje diabetu užívajících vysoce intenzivní terapii statinem

monitorace lačné glykemie má být zvážena u starších osob, pacientů s metabolickým syndromem, obezitou a dalšími známkami inzulinové rezistence

AKS - akutní koronární syndrom ALT - alaninaminotransferáza CK - kreatinkináza $\mathrm{HbA}_{1 c}$ - glykovaný hemoglobin ULN - horní limit referenčního rozmezí/Upper Limit of Normal 
tie nebo rabdomyolýza), veřejnost (laickou i odbornou) znepokojuje, že statiny mohou zpưsobit méně závažné svalové př́znaky. $S$ touto statinovou intolerancí a pseudointolerancí (symptomy s léčbou statiny nemají vůbec přícinnou souvislost) se setká řada lékařủ v terénu a je obtížně řešitelná. Randomizované studie srovnávající statin zaslepeně s placebem velmi přesvědčivě ukázaly, že skutečná nesnášenlivost statinů je vzácná a že je většinou možné nějakou formu terapie statiny podávat (např. jiný statin, upravená dávka, alternativní dávkování).

10. Léčba statiny u osob vyššího věku. Metaanalýzy randomizovaných studií ukázaly, že účinky léčby statiny jsou determinovány absolutní dosaženou redukcí LDL-C a mírou rizika ASKVO před zahájením léčby. Důležité je, že jsou tyto účinky nezávislé na ostatních rizikových faktorech včetně věku. $Z$ toho vyplývá, že terapie statiny u seniorů má vycházet ze stejných principů a být vedena stejně jako u mladších. Zvláštní pozornost vyžaduje zhodnocení celkového zdravotního stavu a možných lékových interakcí. Méně dat máme pro léčbu statiny u osob starších 75 let, zejména $v$ primární prevenci. U populace seniorů se obecně doporučuje zahajování terapie nižšími dávkami a jejich titrací k dosažení cílových hodnot LDL-C.

\section{Literatura}

1. Mach F, Baigent C, Catapano AL et al. [ESC Scientific Document Group]. 2019 ESC/EAS Guidelines for the management of dyslipidaemias: lipid modification to reduce cardiovascular risk. Eur Heart J 2019; pii: ehz455. Dostupné z DOI: <http://dx.doi.org/10.1093/eurheartj/ ehz455>.

2. Catapano AL, Graham I, De Backer J et al. 2016 ESC/EAS Guidelines for the Management of Dyslipidaemias. Eur Heart J 2016, 37(39): 29993058. Dostupné z DOI: <http://dx.doi.org/10.1093/eurheartj/ehw272>.

3. Vrablík M, Pitha J, Blaha $V$ et al. Stanovisko výboru ČSAT k doporučením ESC/EAS pro diagnostiku a léčbu dyslipidemií z roku 2016. AtheroRev 2017; 2(3): 185-193.

4. Soška V, Franeková J, Friedecký B et al. Společné stanovisko českých odborných společností ke konsenzu European Atherosclerosis Society a European Federation of Clinical Chemistry and Laboratory Medicine $\mathrm{k}$ vyšetřování krevních lipidů a $\mathrm{k}$ interpretaci jejich hodnot. AtheroRev 2017; 2(1): 33-39.
5. Češka R, Táborský M, Vrablík M. Společné stanovisko odborných společností k předepisování PCSK9 inhibitorů. Vnitř Lék 2018; 64(12): 1131-1136.

6. Soška V, Vrablík M, Blaha V et al. Indikace PCSK9 inhibitorů v nové léčbě hypercholesterolemie v zorném poli ČSAT. Hypertenze a KV prevence 2016; 5(1): 33-35.

7. Vrablík M, Češka R, Blaha V et al. Souhrn konsenzu panelu expertů European Atherosclerosis Society k otázce diagnostiky a klinickému vedení nemocných s homozygotní formou familiární hypercholesterolemie. Hypertenze a KV prevence 2015; 4(2): 59-61.

8. Urbanová Z, Freiberger T, Šamánek $M$ et al. Komentár̆ k souhrnu konsenzu panelu expertů European Atheroslerotic Society k otázce optimalizace diagnostiky a léčby dětí s familiární hypercholesterolemií. Hypertenze a KV prevence 2016; 5(1): 36-38.

9. Pitha J, Štulc T, Janota $T$ et al. Léčba statiny u pacientů s akutním koronárním syndromem. Interv Akut Kardiol 2012; 11(2): 89-90.

10. Oštádal $P$, Táborský $M$, Linhart $A$ et al. Stručný souhrn doporučení pro dlouhodobou péči o nemocné po infarktu myokardu. Cor Vasa 2019; 61(5); v tisku.

11. Koskinas KC, Windecker S, Pedrazzini G et al. Evolocumab for Early Reduction of LDL-Cholesterol Levels in Patients with Acute Coronary Syndromes (EVOPACS). J Am Coll Cardiol. 2019; pii: S07351097(19)36274-6. Dostupné z DOI: <http://dx.doi.org/10.1016/j. jacc.2019.08.010>

12. Baigent C, Blackwell L, Emberson J et al. [Cholesterol Treatment Trialists' (CTT) Collaboration]. Efficacy and safety of more intensive lowering of LDL cholesterol: a meta-analysis of data from 170,000 participants in 26 randomised trials. Lancet 2010; 376(9753): 1670-1681. Dostupné z DOI: <http://doi: 10.1016/S0140-6736(10)61350-5>.

13. Cannon CP, Blazing MA, Giugliano RP et al. [IMPROVE-IT Investigators]. Ezetimibe Added to Statin Therapy after Acute Coronary Syndromes. N Engl J Med 2015; 372(25): 2387-2397. Dostupné z DOI: <http:// doi: 10.1056/NEJMoa1410489>.

14. Sabatine MS, Giugliano RP, Keech AC et al. [FOURIER Steering Committee and Investigators]. Evolocumab and Clinical Outcomes in Patients with Cardiovascular Disease. N Engl J Med 2017; 376(18): 17131722. Dostupné z DOI: <http://doi: 10.1056/NEJMoa1615664>.

15. Schwartz GG, Steg PG, Szarek M et al. [ODYSSEY OUTCOMES Committees and Investigators]. Alirocumab and Cardiovascular Outcomes after Acute Coronary Syndrome. N Engl J Med 2018; 379(22): 2097-2107. Dostupné z DOI: <http://doi: doi: 10.1056/NEJMoa1801174>.

\section{prof. MUDr. Michal Vrablík, Ph.D. $\triangle$ michal.vrablik@athero.cz}

Centrum preventivní kardiologie, III. interní klinika - endokrinologie a metabolismu 1. LF UK a VFN v Praze

www.vfn.cz

Doručeno do redakce 1. 11. 2019 